\title{
Practical Data Curation
}

\section{for Reproclucjojljty}




\section{Semantics}

- Not the point of this presentation

- Using these terms informally:

- Curation

- Data management

- Replication

\section{YOU KEEP USING THAT WORD.}

- Reproducibility

- Etc. 


\section{Broad definition of validation}

\begin{tabular}{|c|c|c|}
\hline Tyре & Example Files & Use \\
\hline Verification* & $\begin{array}{l}\text { Original Dataset } \\
\text { Original Code }\end{array}$ & $\begin{array}{l}\text { Original Dataset } \\
\text { Original Code }\end{array}$ \\
\hline Reanalysis* & Original Dataset & $\begin{array}{l}\text { Original Dataset } \\
\text { New or Altered Computer Code }\end{array}$ \\
\hline Reproduction* & Original Code & $\begin{array}{l}\text { Original Code } \\
\text { New Dataset within Original Population }\end{array}$ \\
\hline Extension* & Original Code & $\begin{array}{l}\text { Original Code } \\
\text { New Dataset within New Population }\end{array}$ \\
\hline Reuse & Original Dataset & $\begin{array}{l}\text { Original Dataset Combined with New Dataset } \\
\text { New Code }\end{array}$ \\
\hline Exact Reproduction & Table/Graph/Chart File & Reproduced in Review Section \\
\hline
\end{tabular}




\section{Reproducibility}

- Answering the question:

"What can I do to make my data usable in the future to relevant stakeholders?"

- Break down in (almost) reverse order

- Data

- Stakeholders

- Future

- Usable 


\section{One size does not fit all}

- No across-the-board template

- Various standards for specific purposes

- Use the strategy that meets your needs 
$\Delta x_{f}=(1-\phi) \bar{x}+\phi \Delta x_{r_{1}}+\mu_{r}^{x}$

$\left|\gamma_{1}\right|<1, j_{2} \neq 0$

FEDERAL RESERVE BANK OF KANSAS CITY

(1.) BGP prowth: $j^{*}$ (2) BGP point

$\Delta x^{*}=\bar{x}$

"What can I do to make my data usable in the future to relevant stakeholders?"
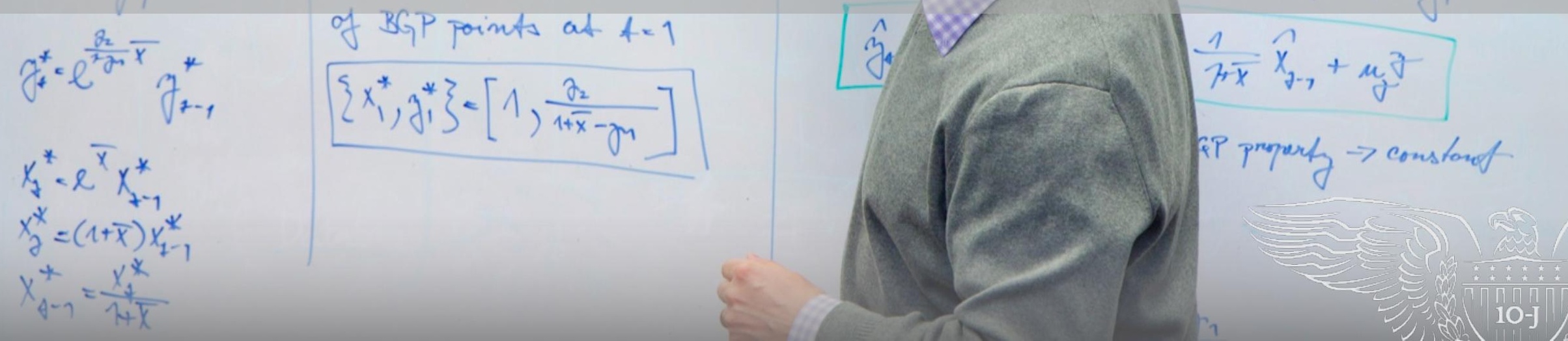


\section{Spectrum of (research) types}

Federal Reserve Bank of Kansas City - Denver - Ohlahoma City - Omaha

A | Banking | Research \& Data | Community Development | Newsroom | Publications | Education I About Us

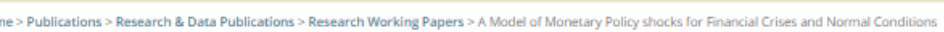

Research Working Paper

A Model of Monetary Policy shocks for Financial Crises and Normal Conditions

By John W. Keating, Logan J. Kelly, A. Lee Smith and Victor J. Valcarcel

\section{Q}

D A Model of Monetary Policy Shocks for Financial Crises and Normal Conditions

Download paper, RWP 14-11, February 16, 2018

Deteriorating economic conditions in late 2008 led the Federal Reserve to lower the target federal funds rate to near zero, inject liquidity into the financial system through novel facilities, and engage in large scale asset purchases. The combination of conventional and unconventional policy measures prevents using the effective federal funds rate to assess the effects of monetary policy beyond 2008. This paper develops an approac to identify the effects of monetary policy shocks in such instances. We employ a newly created broad monetary aggregate to eicit the effects of

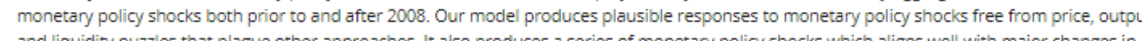
se programs.

JEL Classification: E3; E4; ES

Article Citation

- Keating, John W., Logan I. Kelly, A. Lee Smith, Victor . Valcarcel. 2018. "A Model of Monetary Policy Shocks for Financial Crises and Norma Conditions," Federal Reserve Bank of Kansas City, working paper no. 14.11, February, available at https://doi.org/10.18651/RWP2014.11 Related Research

Christiano, Lawrence L, Martin Eichenbaum, and Charles L Evans. "Monetary policy shocks: What have we learned and to what end?"

Handbook of macroeconomics 1 (1999): 65-148.

- Belongia, Michael T., and Peter N. Ireland. "Interest rates and money in the measurement of monetary policy." Journol of Business \& Economic Stotistics 33.2 (2015): 255-269.
$P F=P$ Find \& Analyze Data

Economic Behavior of the Affluent, 1964 (ICPSR 7429)

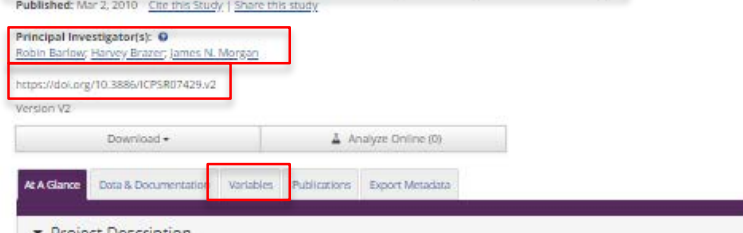

- Project Description

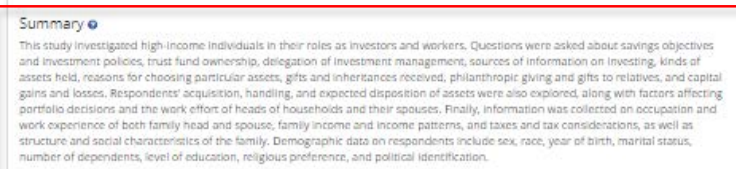

number c ape

Citation $\bullet$

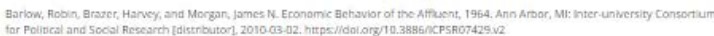

Export clation:

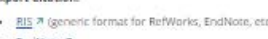

Funding o

Funding 0

Ford foundation

Subject Terms $\bullet$

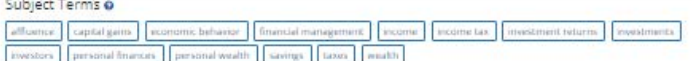

- Scope of Project

- Methodology

- Version(s)

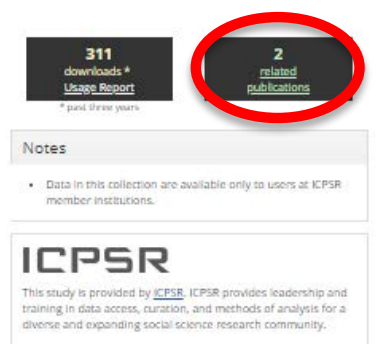

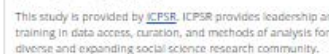




\section{And everything in between}

- Source data (primary or secondary)

- Excerpted data

- Intermediate data

- Final (output) data

- Code 


\section{"What can I do to make my data usable} in the future to relevant stakeholders?"

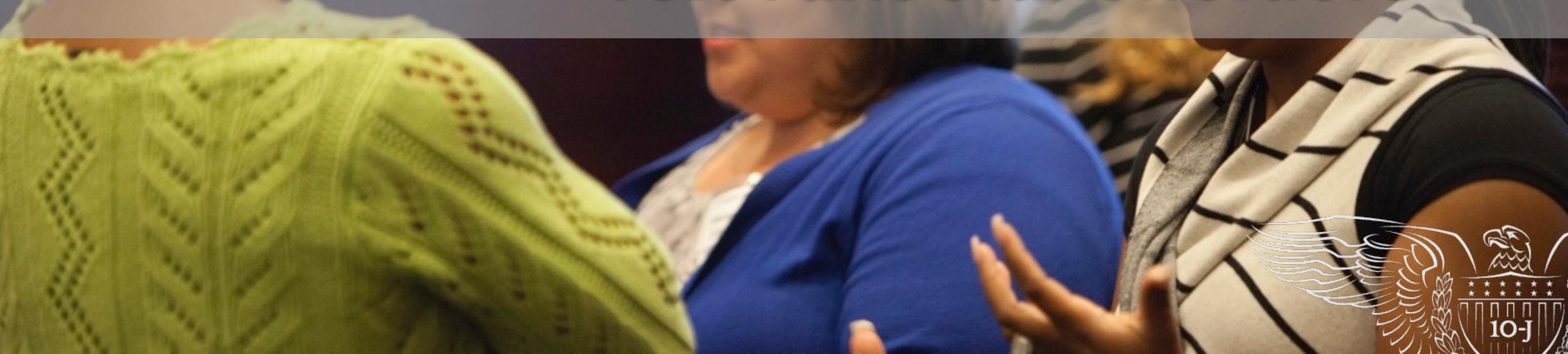




\section{Who are you doing this for?}

- Public trust and confidence

- Reproducibility Crisis

- Loss of trust in public institutions

- Internal operations

- Passing the baton

- Record retention guidelines
- Policies and mandates

- Journals

- Funders

- Yourselves

- Increase citations? 


\section{Oh fun, more work}

- The "right thing to do" is not always terribly incentivizing for day-to-day tasks

- Journal/funder/audit mandates = bare minimums

- Researcher = \#1 stakeholder

- Curate for you! 


\section{Often separate processes}

Research Data

Management

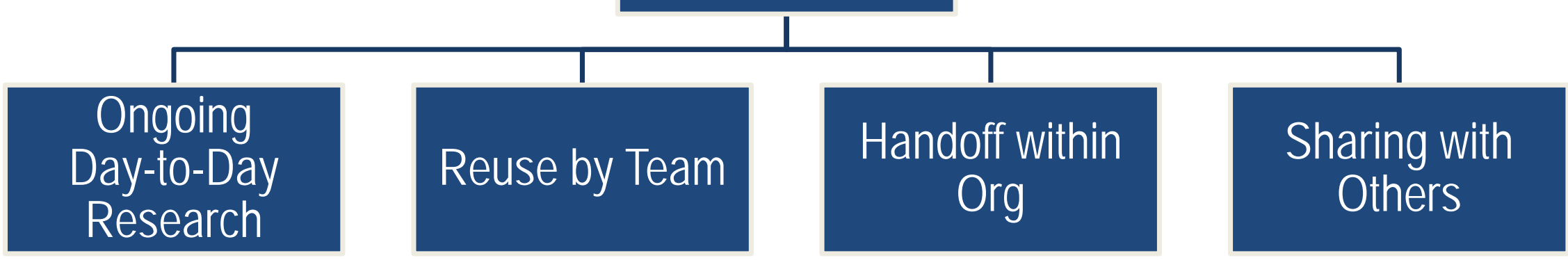




\section{Build incrementally}

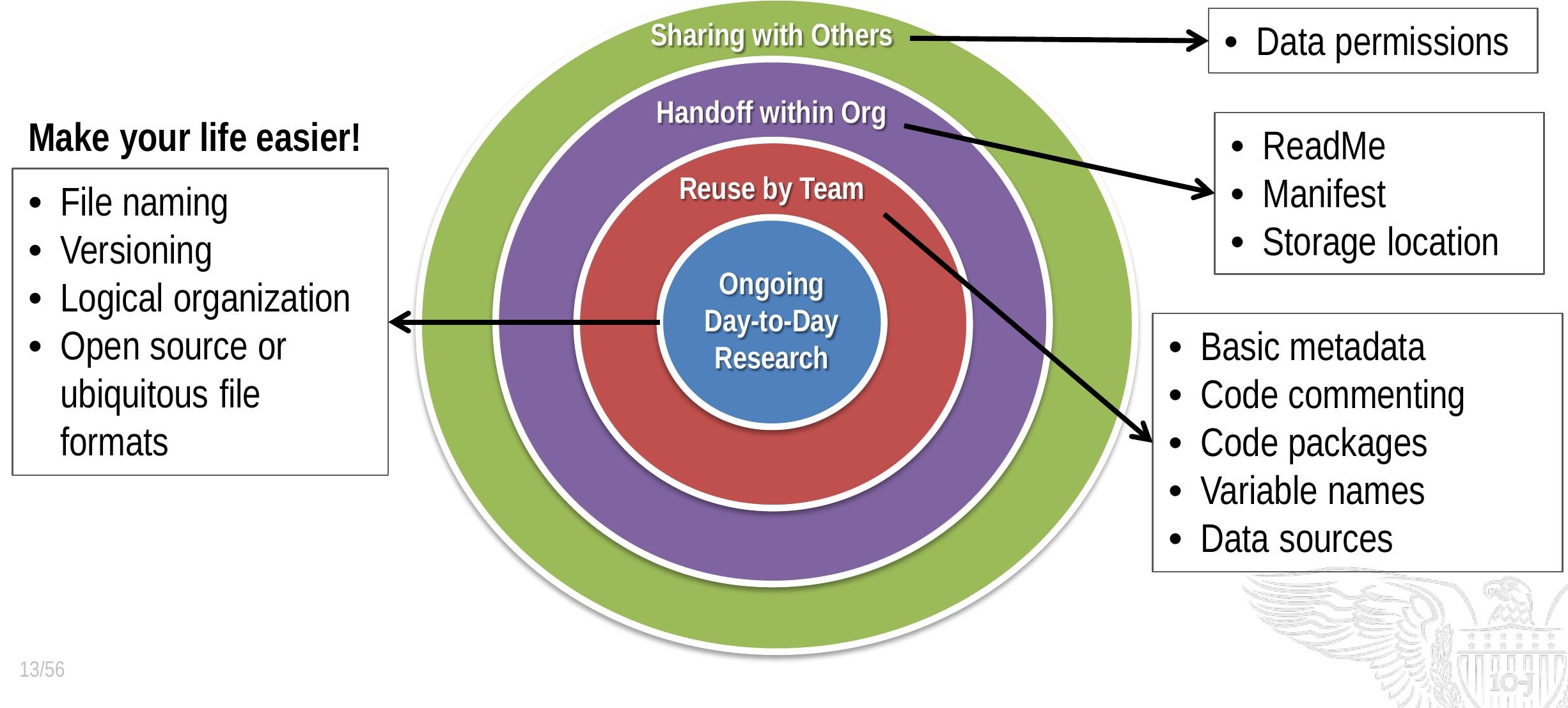




\section{Not as bad as it seems}

- Reproducibility can get a bad rap

- compliance

- second-guessing of results

- Reproducibility practices can make life easier research integrity is a bonus! 


\section{Our method}

- Make recommendations

- Provide evidence, reasoning, support, horror stories

- Up to researcher what makes most sense 


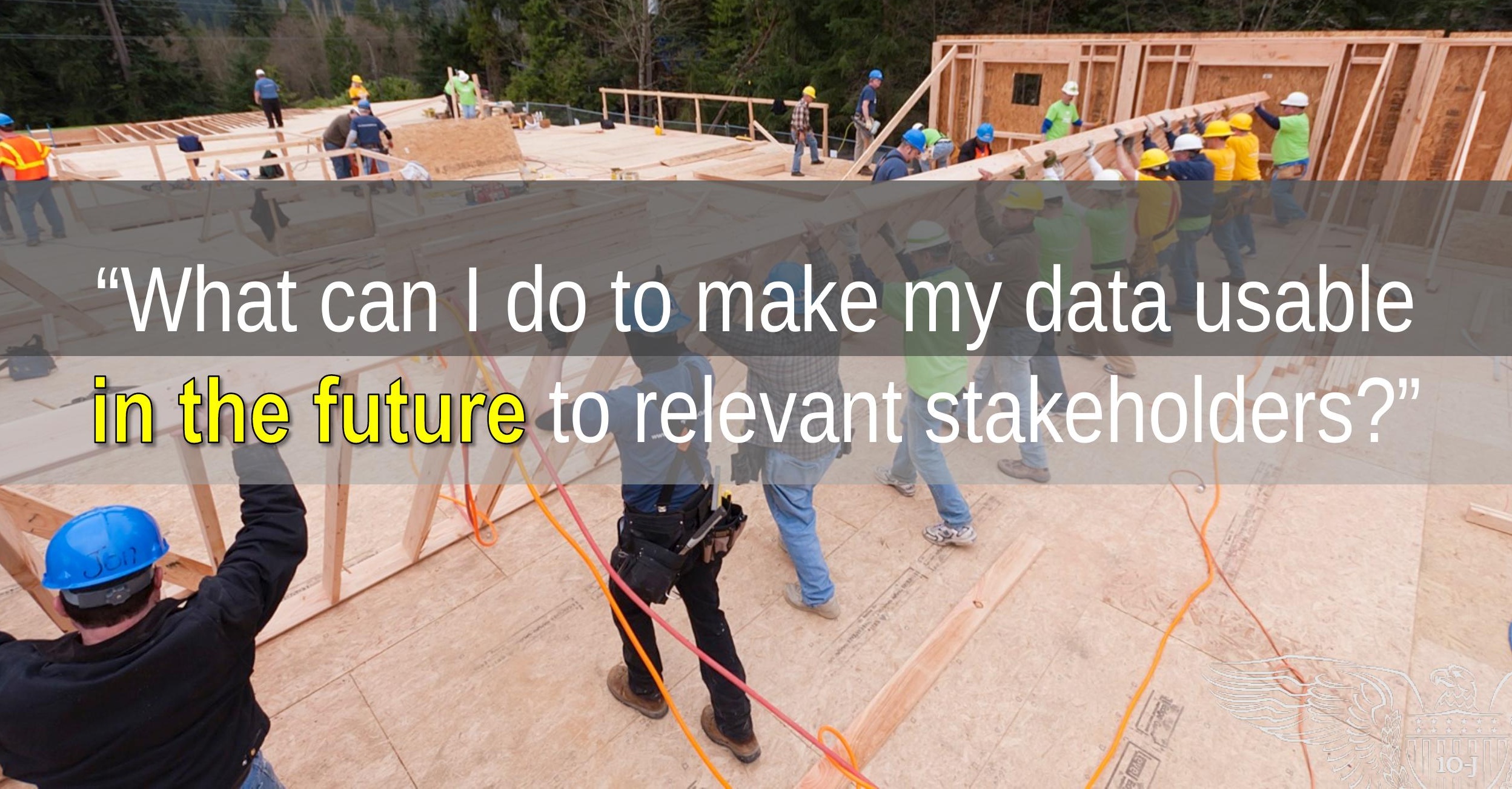




\section{You can't reproduce what doesn't exist}

- A data/code file not being actively preserved is at risk of:

- Bit rot/file corruption

- Obsolescence

- Personal knowledge loss

- Disappearance into the abyss (no inventory)

- Preservation is necessary to ensure reproducibility in 1, 5, 10, 20+ years (economic research half-life) 


\section{Preservation mechanisms}

- Established repositories are experts

- Use their expertise!

- Restricted data can get tricky 


\section{DIY projects}

- Strategy

- Technology agnostic

- SaaS - Open source is like free puppies

- Preservation platform $\neq$ discovery platform 


\section{Desirable features}

- Software

- OAIS compliance (ISO 14721)

- 3-2-1 backup

- Fixity repairs

- File format migration

- User Friendly

\section{- Process}

- Dedicate point person(s)

- Coordination, consistency

- Manage timelines/expectations

- Manual work, reduce burden

- Accept everything

- Automate when possible 

in the future to relevant stakeholders?" 


\section{Just three little topics}

- Permissions and Restrictions

- Metadata/Documentation

- File Handling 
Permissions and Restrictions 


\section{Where do restrictions come from?}

\section{Primary Data}

- IRB Study

- Non-disclosure agreement to participants

- End User License Agreement

- Site License

- State Law

- Federal Law

\section{Secondary Data}

- End User License Agreement

- Site License

- State Law

- Federal Law

- Formal Contracts 


\section{Restrictions}

- At a minimum, understand the terms

- Even better, negotiate better terms!

- Don't be afraid to ask for additional permissions later

- Note: this is not a "better to ask for forgiveness" situation 


\section{Checklist}

- Publications

- Review requirements

- Citations

- Reporting
- Data

- Sharing internally, externally

- Authorized users (co-authors)

- Aggregation levels

- Termination

- Continued use

- Preservation/purging 


\section{Pay it forward}

- Specify restrictions in documentation

- Proprietary vendors will be appreciative!

- Do not give permissions that you do not have the authority to give

*Any data provided herein is provided pursuant to a license between the data provider and the Federal Reserve Bank of Kansas City, is proprietary, and may not be redistributed. The Federal Reserve Bank of Kansas City does not own the data and cannot authorize its redistribution to any other party. Please contact the data provider for any questions concerning redistribution of the included data. 


\section{Metadata and Documentation}




\section{Legitimate products of research}

- Force11 Principle \#1:

"Data should be considered legitimate, citable products of research. Data citations should be accorded the same importance in the scholarly record as citations of other research objects, such as publications." 


\section{Citations}

- For your data

- For the data sources

- Formatting not yet standardized but should include:

- Title

- Author/Creator

- Publication Date
-- Persistent Identifier

-- Publisher/Distributor 


\section{Legitimate products of research}

- Force11 Principle \#1:

"Data should be considered legitimate, citable products of research. Data citations should be accorded the same importance in the scholarly record as citations of other research objects, such as publications."

\section{- Take it a step further:}

Data should be considered legitimate, discoverable products of research. Data metadata should be accorded the same importance in the scholarly record as metadata of other research objects, such as publications. 


\section{Typical article metadata}

- Title

- Author, Affiliations

- Abstract

- Keywords

- Citation

- Date(s)
- Identifier (e.g., DOI)

- Copyright

- References

- Publisher

- Funding 


\section{What's missing?}

- Data Collector / Producer

- Sampling and Sampling Procedures

- Weighting

- Substantive, Temporal and Geographic Coverage

- Data Source(s)

- Unit(s) of Analysis / Observation

- Variables

- Technical Information on Files

- Data Collection Instruments
- Flowchart of the Data Collection Instrument

- Abbreviations and Other Conventions

- Interviewer Guide

- Coding Instrument

- And more... 


\section{Helpful context}

Job Opening and Labor Turnover Survey

The Job Opening and Labor Turnover Survey
JOLTS) is a monthly dataset that samples
approximately 16,400 private, nonfarm
establishments and government offices
regarding job openings, hires and separations.

The Job Opening and Labor Turnover Survey (JOLTS) is a monthly dataset that samples private, nonfarm establishments and government offices regarding employment. Specifically, JOLTS asks approximately 16,400 establishments several questions about employment, job openings, hires, and separations. Participating establishments provide data for up to 24 months. These data are publicly available back to December 2000 and are collected by the Bureau of Labor Statistics.

The JOLTS Museum Room

\section{Data Access}

Data for the Job Opening and Labor Turnover Survey (JOLTS) can be found on FRED or on the BLS website

Key Concepts

Information on the content of the JOLTS data. Specifically, the purpose of the survey, details and definitions of the main data series, and technical information

Related Research

A sample of Federal Reserve System research that uses JOLTS data.

Metadata at a Glance (Full Metadata)

Sample population or universe: Private, nonfarm U.S. establishments and government offices

Collection method: Survey, participants provide data for up to 24 months

Frequency and timeframe: Monthly since December 2000

Notion of dimension: 16,400 in scope establishments each month give data for half a dozen data series

Purpose and main content: Provides information on employers with regards to employment, job openings, hires, and separations Access and use information: Publicly available

Producer and publisher: Bureau of Labor Statistics
Federal Reserve Bank of Kansas City - Denver - Ollahoma City - Omaha

* | Banking | Research \& Data | Community Development I Newsroom | Publications | Education | About Us

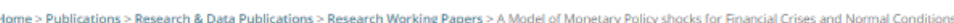

Research Working Paper

A Model of Monetary Policy shocks for Financial Crises and Normal Conditions By John W. Keating, Logan J. Kelly, A. Lee Smith and Victor J. Valcarcel

\section{Q 80}

D A Model of Monetary Policy Shocks for Financial Crises and Normal Conditions

Download paper, RWP 14.11, February 16, 2018

Deteriorating economic conditions in late 2008 led the Federal Reserve to lower the target federal funds rate to near zero, inject liquidity into the financial system through novel facilities, and engage in large scale asset purchases. The combination of conventional and unconventional policy measures prevents using the effective federal funds rate to assess the effects of monetary policy beyond 2008 . This paper develops an approach to identify the effects of monetary policy shocks in such instances. We employ a newily created broad monetary aggregate to elicit the effects of monetary policy shocks both prior to and after 2008. Our model produces plausible responses to monetary policy shocks free from price, outpur, and liquidity puzzles that plague other approaches. It also produces a series of monetary policy shocks which aligns well with major changes in the Fed's asset purchase programs.

JEL Classification: E3; E4; E5

Article Citation

- Keating, John W., Logan J. Kelly, A. Lee Smith, Victor J. Valcarcel. 2018. "A Model of Monetary Policy Shocks for Financial Crises and Normal Conditions," Federal Reserve Bank of Kansas City, working paper no. 14.11, February, available at https://doi.org/10.18651/RWP2014-11

Related Research

- Christ d

- Handbook of macroeconomics 1 (1999): $65-148$.

- Belongia, Michael T, and Peter $\mathrm{N}$. Ireland: "Interest rates and money in the measurement of moneran policy." Journol of Business a

Economic Statistics 33.2 (2015): 255-269.

Additional Files

- Appendix

- Replication Code and Da 


\section{ReadMe}

\begin{tabular}{|c|c|c|c|c|}
\hline $\begin{array}{l}\text { Page } 1 \text { of } 3 \\
\text { July } 2018\end{array}$ & & Man & fest & $\begin{array}{l}\text { Page } 2 \text { of } 3 \\
\text { July } 2018\end{array}$ \\
\hline \multirow{2}{*}{ 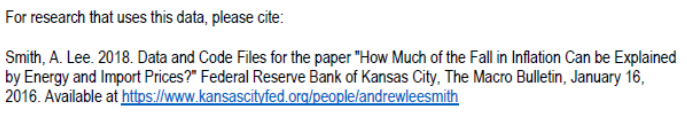 } & Folder & File Name & File Type & Description \\
\hline & \begin{tabular}{|l} 
2018_smithmb- \\
20160115_data-code
\end{tabular} & ReadMe.pdf & PDF & $\begin{array}{l}\text { License, citations, and } \\
\text { information on file types } \\
\text { and use }\end{array}$ \\
\hline $\begin{array}{l}\text { Copyright (c) 2018, Andrew Lee Smith and the Federal Reserve Bank of Kansas City. All rights reserved. } \\
\text { Redistribution and use in source and binary forms, with or without modfication, are permitted provided that } \\
\text { the following conditions are met. }\end{array}$ & $\begin{array}{l}\text { 2018_smith_mb- } \\
\text { 20160115_data-code }\end{array}$ & oil_var_labels.xlsx & $\begin{array}{l}\text { Microsoft Excel } \\
\text { Worksheet }\end{array}$ & \\
\hline \multirow{2}{*}{$\begin{array}{l}\text { "Redistrbutions of source code must retain the above copyright notice, this list of conditions and the } \\
\text { following disclaimer. } \\
\text { "Redistributions in binary form must reproduce the above copyright notice, this list of conditions and the } \\
\text { following disclaimer in the documentation and lor other materials provided with the distribution. }\end{array}$} & \begin{tabular}{|l} 
2018_smith_mb- \\
20160115_data-code
\end{tabular} & rats_var_code.RPF & $\begin{array}{l}\text { RATS Program } \\
\text { File }\end{array}$ & $\begin{array}{l}\text { This is the main script } \\
\text { that produces the output } \\
\text { used to create Figure } 2 \\
\text { in The Macro Bulletin }\end{array}$ \\
\hline & $\begin{array}{l}\text { 2018_smithmb- } \\
\text { 20160115_data-code }\end{array}$ & mcfevdtable.src & RATS Source File & \\
\hline $\begin{array}{l}\text { "Neither the name "Federal Reserve Bank of Kansas City" nor the names of its contributors may be used } \\
\text { to endorse or promote products derived from this software without specific prior witten permission. }\end{array}$ & $\begin{array}{l}\text { 2018_smith_mb- } \\
\text { 20160115_data-code }\end{array}$ & mcgraphirf.scc & RATS Source File & \\
\hline 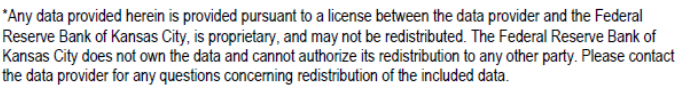 & \begin{tabular}{|l|}
2018 smith_mb- \\
20160115_data-code
\end{tabular} & movardodraws.src & RATS Source File & \\
\hline $\begin{array}{l}\text { THIIS SOFTWARE IS PROVIDED BY THE COPYRIGHT HOLDERS AND CONTRIBUTORS "AS IS" AND } \\
\text { ANY EXPRESS OR IMPLIED WARRANTIIS, INCLUDING, BUT NOT LIMITED TO, THE IMPLIED }\end{array}$ & \begin{tabular}{|l} 
2018_smith_mb- \\
20160115_data-code
\end{tabular} & varlagselect.src & RATS Source File & \\
\hline
\end{tabular}

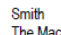

WARRATIES OF MECED WAT

WISCLAMED IN NO EVENT SHALI THE COPYRIGHT HOLDER OR CONTRIBUTORS BE LABLE FOR ANY DIRECT, INDIRECT, INCIDENTAL, SPECIAL, EXEMPLARY, OR CONSEQUENTALL DAMAGES (NCLUDNG, BUT NOT LIMTIED TO, PROCUREMENT OF SUBSTIIUTE GOODS OR SERVICES; LOSS THEORY OF LIABUTY WHETHER IN CONTRACT STRICT LABUTY OR TORT INAUDNG NEGLIGENCE OR OTHERWISEE ARISING IN ANY WAY OUT OB THE USE OF THIS SOFTWARE,
EVEN IF ADVISED OF THE POSSIBLITY OF SUCH DAMAGE.

\section{Data Citations}

Bureau of Economic Analysis (BEA). 2015. Personal Consumption Expenditures (PCE). January 1985 October 2015. Accessed through Haver Analytics

Bureau of Economic Analysis (BEA). 2015. Personal Consumption Expenditures (PCE) excluding food and 1985 -October 2015 Accessed through Haver Analytics

Bureau of Labor Statistics (BLS). 2015. Consumer Price Index (CPI). January 1985 - October 2015 Federal Reserve Board of Govemors. 2015. Foreign Exchange Rates - G.5 Monthly: Broad. January 1985
- October 2015. Accessed through Haver Analytics.

London Baltic Exchange. 2015. Baltic Dry Index (BDI). January 1985 - October 2015. Accessed through
Thomson Reuters.

U.S. Energy Information Administration (EIA). 2015. Production of Crude Oil including lease condensate. Wall Street Journal and U.S. Energy Information Administration (EEA)'. 2015. Spot Price Crude Oil West
Texas Intermediate (WTI). January 1985 - August 2015. Accessed through Haver Analytics.

Sniti

The Macro Bulletin, January 16, 201

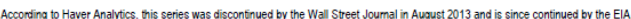
Smith

The Macro Bulletin, January 16, 2016 


\section{ReadMe}

- Project description

- List of authors with contact info

- Information on use

- Configuration, dependencies

- Compiled? Inputs, outputs

- Mechanism(s) to provide feedback 


\section{Embeddedness}

- Metadata contained with the object itself; or

- Metadata applied within a content management system; or

- Metadata embedded within a related file in the same collection 


\section{Description level}

- Describing individual objects can be resource-intensive; collection description usually more efficient

- Examples of when to consider granular description:

- Security restrictions on the source dataset differ from the calculated results

- no need to restrict the whole collection

- Code requires a specific version of software to run

- don't want to lose context 


\section{Examples}

\begin{tabular}{|l|l|l|}
\hline Field & Embeddedness* & Hierarchical Level* \\
\hline Title & File & File \\
\hline Author & File & Collection \\
\hline File format & Associated File (ReadMe) & File \\
\hline License & Associated File (ReadMe) & Collection \\
\hline Access Rights & Applied & File \\
\hline Subject & Applied & Collection \\
\hline
\end{tabular}

*Lowest level, could also be included at higher levels 


\section{Cat is out of the bag}

- Make (some) metadata available for restricted data

- If they can know the data exists, they can know something about it

- Can help with understanding research

- Can help determine if obtaining access is possible and/or worthwhile 


\section{Seven core characteristics}

- Sample Population or Universe

- Collection Method

- Frequency and Timeframe

- Notion of Dimension

- Purpose and Main Content

- Access and Use Information

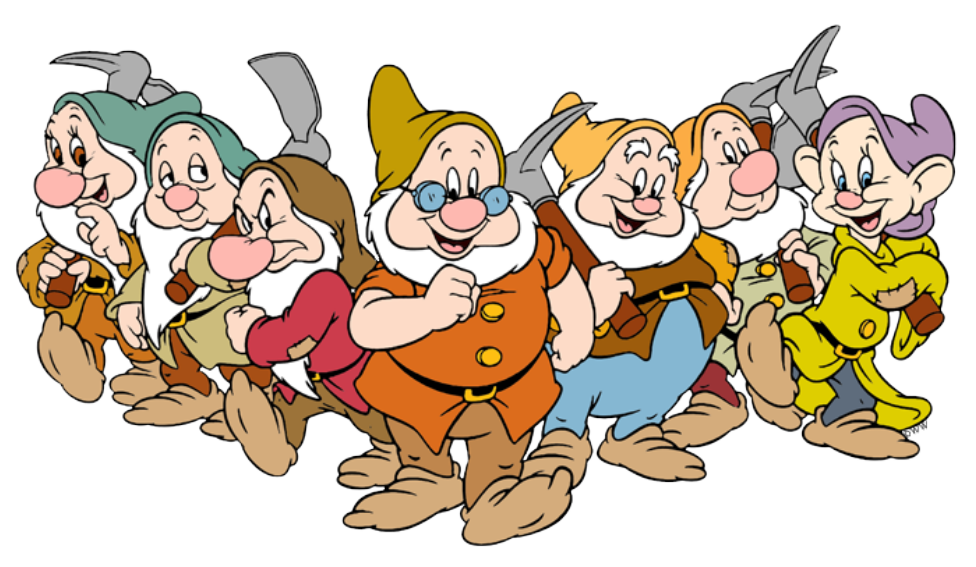

- Producer or Publisher 


\section{Examples}

\section{Current Population Survey}

The Current Population Survey is a monthly address-based survey of U.S. households that gathers geographic, demographic, and employment status information. These data are used to calculate several national indicators of employment, such as the unemployment rate and labor force participation. In its current iteration, data on over 150,000 respondents are collected monthly to create around 400 variables. The CPS survey data are collected by the Census on behalf of the Bureau of Labor Statistics and $42 / 56$ are publically available dating back to 1976.

Job Opening and Labor Turnover Survey

The Job Opening and Labor Turnover Survey

(UOLTS) is a monthly dataset that samples

approximately 16,400 private, nonfarm

establishments and government offices

regarding job openings, hires and separations.
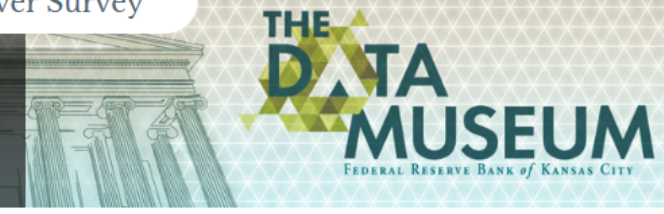

The Job Opening and Labor Turnover Survey (OLLS) is a monthly dataset that samples private, nonfarm establishments and government offices regarding employment. Specifically. JOLTS asks approximately 16,400 establishments several questions about government offices regarding employment. Specifically, JOLTS asks approximately 16,400 establishments several questions about
employment, job openings, hires, and separations. Participating establishments provide data for up to 24 months. These data are publicly available back to December 2000 and are collected by the Bureau of Labor Statistics.

The JOLTS Museum Room

Data Access

Data for the Job Opening and Labor Turnover Survey (JOLTS) can be found on FRED or on the BLS website.

Key Concepts
Information on the content of the JOLTS data. Specifically, the purpose of the survey, details and definitions of the main data series, and technical information.

Related Research

A sample of Federal Reserve System research that uses JOLTS data.

Metadata at a Glance (Full Metadata)

Sample population or universe: Private, nonfarm U.S. establishments and government offices

Collection method: Survey, participants provide data for up to 24 months

Frequency and timeframe: Monthly since December 2000

Notion of dimension: 16,400 in scope establishments each month give data for half a dozen data series

Purpose and main content: Provides information on employers with regards to employment, job openings, hires, and separations.

Access and use information: Publicly available

Producer and publisher: Bureau of Labor Statistics 


\section{Multiple metadata mapping}

- Don't expect one schema or standard to meet all needs

- Be careful with frankenschemas

- Map similar terms

- title should mean the same thing across relevant schemas

- Consider a repository

- Help illuminate both consistencies and inconsistencies 
File Handling 


\section{Naming}

- Use meaningful names (i.e., NOT draft1)

- Use lower case (hyphens, underscores)

- Standardize dates (ISO YYYY-MM-DD)

- Ex: 2018_smith_mb-20160115_data-code Ex: 20180618_butler_data-citation_twp 


\section{Formats and organization}

- Work in open source or ubiquitous formats

- Document or provide open source alternatives

- Organize logically

- Use relative paths in code
ResearchProject/

- data/

— timeSeries1.csv

— timeSeries2.csv

out/

— result20170619.out

— result20170622.out result20170624.out

README

src/

- functions/

$\vdash$ filel0.py regression.py

Main.py 


\section{Variable naming}

- Clear but succinct

- Too long: variable_for_iterating_over_loop

- Too short: i

- Avoid using "tmp" and meaningless 1up numbering (fn1, fn2, ...)

- Be consistent 


\section{Code commenting}

- Files, functions, and classes should have a brief description (what/why)

- "how" not necessary, code should do that

- Provide enough information so the user does not have to read the code to understand

- Expected input(s)/output(s) and data types 


\section{Use small functions}

- Generic, can be shared between projects

- Easier to read, remember

- Easier to update/replace/improve

- Easier to isolate and debug

Suggestion rule of thumb: fit on one page (no scrolling) 


\section{Containerization}

- In addition to data and code, preserve the environment

- Helps with dependency issues (OS, software, libraries, environment variables, etc.)

- Only dependent on container platform (i.e. Singularity, Docker)

- Content of a container operates identically across hardware 


\section{Stack 'em}

- Stackable

- Allows reuse of computing environment across multiple projects
Container2

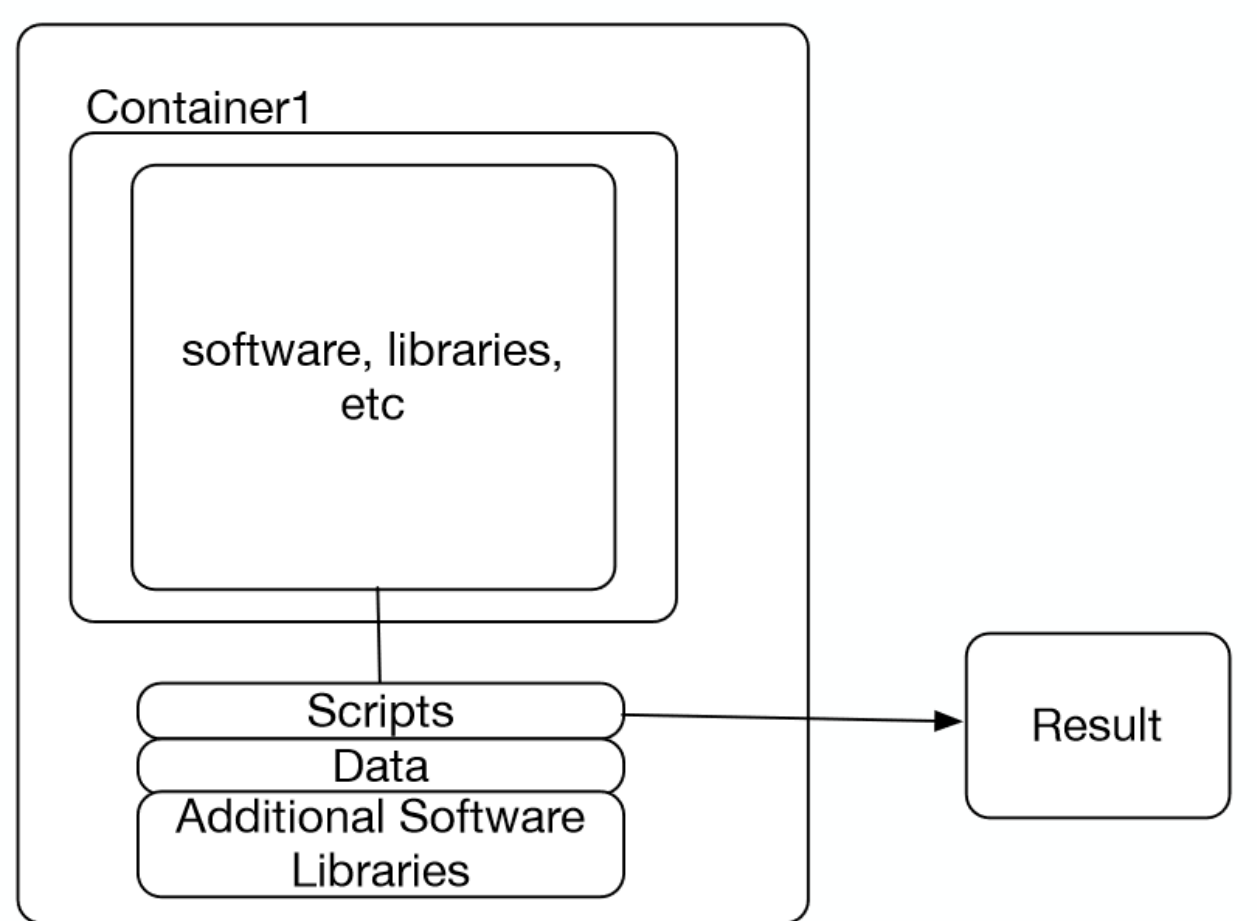




\section{Final Thoughts}

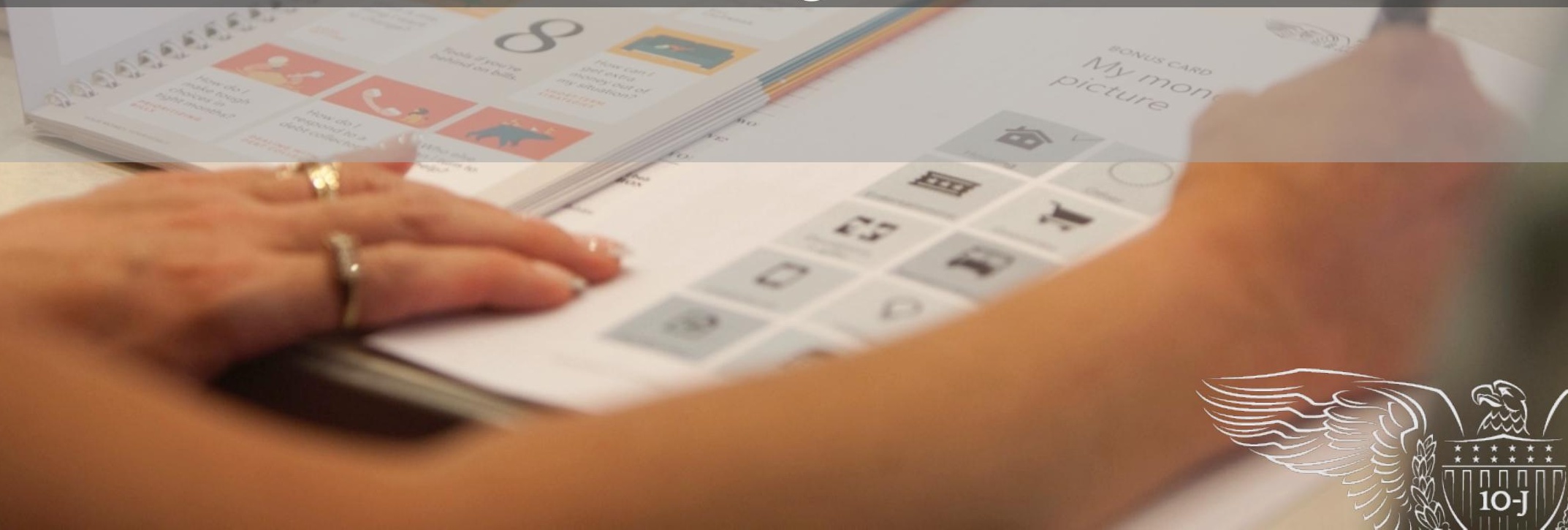




\section{Work from standards}

- No need to reinvent the wheel

- No shortage of resources available

- Helpful community willing to share!

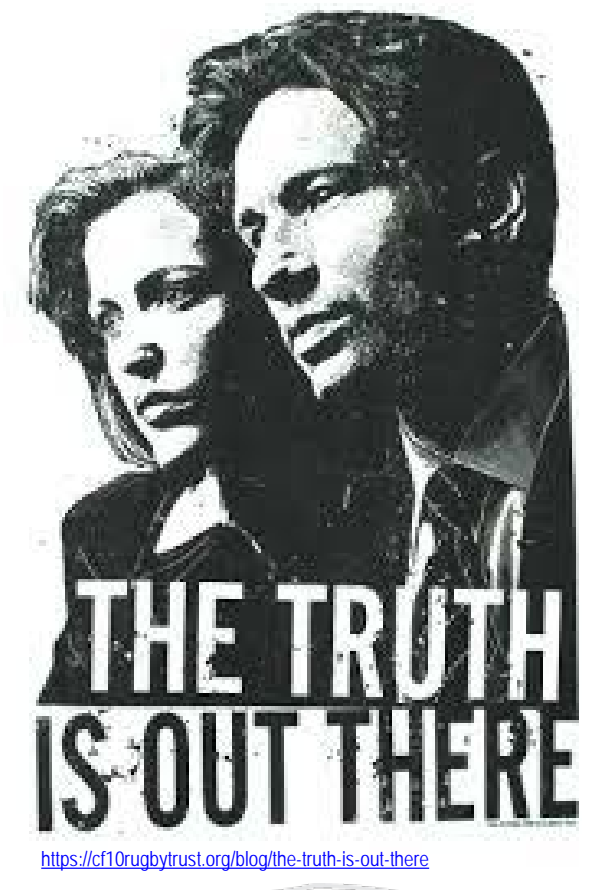




\section{Something is always better than nothing}

- Start with what makes your life easier

- Build practices to meet specific needs

- Simply: describe it, make it usable, keep it around 


\section{Special thanks}

\section{Brett D. Currier}

Thealexa Becker

Greg Woodward

Tom Cook

Christina M. Kulp

A. Lee Smith 


\section{Thank you!}

\section{courtney.butler@kc.frb.org | @infodeke}

